\title{
Mercury and hydroquinone content of skin toning creams and cosmetic soaps, and the potential risks to the health of Ghanaian women
}

\author{
Eric Selorm Agorku, Edward Ebow Kwaansa-Ansah*, Ray Bright Voegborlo, Pamela Amegbletor \\ and Francis Opoku
}

\begin{abstract}
In this study, sixty-two (62) skin-lightening creams and soaps were analysed for total mercury and hydroquinone levels. Total mercury was determined by the Cold Vapour Atomic Absorption Spectrophotometry using an automatic mercury analyser and hydroquinone by High Performance Liquid Chromatography. The mean concentration of total mercury in skin toning creams and cosmetic soaps were $0.098 \pm 0.082$ and $0.152 \pm 0.126 \mu \mathrm{g} / \mathrm{g}$, respectively. The mean concentration of hydroquinone was $0.243 \pm 0.385$ and $0.035 \pm 0.021 \%$ in skin toning creams and cosmetic soaps, respectively. All the creams and soaps analysed had mercury and hydroquinone levels below the US Food and Drug Administration's acceptable limit of $1 \mathrm{\mu g} / \mathrm{g}$ and $2 \%$, respectively. The low levels of mercury and hydroquinone in the creams and soaps analysed in this study therefore do not pose any potential risk to consumers who are mostly women in Ghana.
\end{abstract}

Keywords: Total mercury, Hydroquinone, Skin-lightening, Creams, Soaps

\section{Background}

In most communities across the globe, fairness is branded as beauty, grace and high social status. This perception encourages most women to engage in skin bleaching. Skin-lightening or bleaching has reached epidemic levels in many nations across the world especially in African countries like Ghana, Nigeria, Mali, Kenya and Tanzania (Harada et al. 2001; Adebajo 2002; Mahe et al. 2004; Lewis et al. 2009; Voegborlo et al. 2008). The production of skin-bleaching products is on the rise and in high demand across the world (Perry 2006). Many African women want to keep their skin toned and beautiful by indulging in skin care products that bleach the skin. Most of these bleaching cosmetic products contain different kinds of harmful chemicals such as hydroquinone,

*Correspondence: eekwaansaansah@yahoo.com

Department of Chemistry, Kwame Nkrumah University of Science and Technology, Kumasi, Ghana mercury, kojic acid and vitamin $\mathrm{C}$, which can affect their health (Amponsah et al. 2014).

Cosmetic preparations containing mercury for bleaching purpose is an old practice (Al-Saleh and Al-Doush 1997). Mercury is a toxic metal but found usefulness in many cosmetic preparations targeted at skin lightening by suppression of melanin production by the skin (Bourgeosis et al. 1986). Cosmetic products containing mercury in the form of inorganic mercury are mainly used by dark skinned people mostly in developing countries (Barr et al. 1973). Mercury is a volatile element and is harmful to the skin when used in an effort to lighten the skin. However, chronic exposure of the body to mercury at very low concentration can cause long-lasting neurological and kidney impairment (Hutson et al. 1999). Mercury in bleaching preparations can be absorbed through the skin and accumulates in body organs giving rise to severe toxicity (Sah 2012). A study conducted on Tanzanian gold miners who use mercury for amalgamation and people not engaged in gold mining activities revealed that

\section{望 Springer}

(C) 2016 Agorku et al. This article is distributed under the terms of the Creative Commons Attribution 4.0 International License (http://creativecommons.org/licenses/by/4.0/), which permits unrestricted use, distribution, and reproduction in any medium, provided you give appropriate credit to the original author(s) and the source, provide a link to the Creative Commons license, and indicate if changes were made. 
the mercury found in their blood and urine was derived from cosmetic soaps and creams containing mercury (Kahatano et al. 1998). Glahder and Appell (1999) also reported high levels of mercury in imported soaps and creams bought in Tanzanian shops. An investigation of Kenyan women with damaged kidney also revealed that they suffered severely from higher incidence of nephritic syndrome, which was attributed to the use of creams containing mercury (Barr et al. 1973).

Hydroquinone is a potential carcinogenic ingredient used in skin lightening and treatment of hyper-pigmentation (Joseph et al. 1998). Hydroquinone does not actually bleach the skin but rather, a strong inhibitor of melanin production (Yoshimura et al. 2001). Hydroquinone used for topical application is known to cause serious health hazards when used excessively (Hutson et al. 1999). Hydroquinone toxicity can lead to severe side effects such as kidney and liver malfunction, blood poisoning, nausea, abdominal pains, convulsion and even coma. Animal test on rats, mice and rabbits showed that hydroquinone can cause acute toxicity (Aldrich 1990).

Most of the skins lightening creams and soaps on the Ghanaian market are imported from USA, Europe, Italy and Cote d'Voire (Voegborlo et al. 2008). The demand for skin-lightening products in Ghana is on the increase despite the health hazards associated with the use of these products. However, data on mercury and hydroquinone levels in skin-lightening soaps and creams sold on the Ghanaian market are lacking and only little work has been done on mercury (Voegborlo et al. 2008) even though concerns have been raised on the negative effect of skin-lightening creams and soaps on the skin. The aim of this work was to analyse the mercury and hydroquinone content in some skin toning creams and cosmetic soaps using automatic mercury analyser coupled with Cold Vapour Atomic Absorption Spectrophotometry (CV-AAS) and High Performance Liquid Chromatography.

\section{Methods}

Different brands of cosmetic soaps and creams were bought from retail shops and markets in Ghana. A total of sixty-two (62) skin-lightening products comprising of fifty-four (54) creams and eight (8) soaps were obtained. Samples were transported to the laboratory. The soaps were cut into smaller sizes with a stainless steel knife and kept in clean labelled glass vials prior to chemical analysis.

The samples were digested for total mercury determination by a modified version of an open flask procedure developed at the National Institute for Minamata Disease (NIMD) Japan (Akagi and Nishimura 1991). A blank and standard solution digest using standard $\mathrm{Hg}$ solution were subjected to the same treatment. Determination of mercury in all the digests were carried out by CV-AAS using an Automatic Mercury Analyser, Model HG-5000 (Sanso Seisakusho Co., Ltd, Japan) equipped with mercury lamp operated at a wavelength of $253.7 \mathrm{~nm}$.

Hydroquinone in all the samples were extracted with ethanol. About $0.10 \mathrm{~g}$ of each cream and soap was weighed into a $10 \mathrm{ml}$ flask and $8.0 \mathrm{ml}$ of methanol was added and heated at $40{ }^{\circ} \mathrm{C}$ in a water bath and shaken occasionally until it dissolved. The mixture was allowed to cool and made up to the mark with methanol. The solution was filtered using a sintered glass filter with a vacuum pump. Blank and standard hydroquinone solutions were subjected to the same treatment. Determination of hydroquinone was carried out by a chromatographic method using a High Performance Liquid Chromatography, Model Varian 325 (England) equipped with UV/visible and fluorescence detector.

\section{Method validation}

Replicate blanks, recovery tests and reference materials (DORM-2) from the National Research Council (NRC) of Canada were used for the method validation and quality control. The validity of the method has been proved by the agreement between the measured (4.64$4.81 \mu \mathrm{g} / \mathrm{g}$ ) and certified (4.21-4.83 $\mu \mathrm{g} / \mathrm{g}$ ) concentrations in DORM-2 Certified Reference Material. Recovery studies were performed by adding increasing amounts of mercury and hydroquinone standard solutions to three different samples, which were separately taken through similar digestion and extraction procedures respectively. Accepted values range from 95 to $110 \%$ (Miller and Miller 1988). Analytical and matrix recovery studies for mercury ranged from 97 to $102 \%$ with coefficient of variation between 4 and $9 \%$. The recovery studies of hydroquinone yielded results between 98 and $103 \%$. The coefficients of variation of hydroquinone concentration in triplicates were between 0.19 and $4.73 \%$. This shows that the method is accurate and fit for analysis of the above parameters.

\section{Results and discussion}

In all the samples analysed, T-mercury levels ranged from $<0.001$ to $0.327 \pm 0.062 \mu \mathrm{g} / \mathrm{g}$ and hydroquinone concentration ranged from below detection to $1.61 \pm 0.72 \%$. The results for T-mercury and hydroquinone concentrations in skin toning creams and cosmetic soaps are shown in Tables 1 and 2.

Majority of the skin-lightening creams analysed in this study originated for Cote d'Voire (34 \%), Italy (30\%) and India (13\%). The rest originated from UK, USA, Senegal, China, Germany, Nigeria and Ghana. T-mercury concentration $(\mu \mathrm{g} / \mathrm{g})$ in the skin-lightening creams imported 
Table 1 Levels of mercury and hydroquinone concentrations in skin toning creams

\begin{tabular}{|c|c|c|c|c|}
\hline Product name & $\begin{array}{l}\text { Acronym } \\
\text { for product }\end{array}$ & Mercury $(\mu \mathrm{g} / \mathrm{g})$ & Hydroquinone (\%) & Country of origin \\
\hline Akagni ${ }^{\circledR}$ Skin Toning Cream & AKS & $0.129 \pm 0.057$ & $0.21 \pm 0.16$ & Cote d'Voire \\
\hline Body White & BW & $<0.001$ & ND & Cote d'Voire \\
\hline Carotone & CT & $0.147 \pm 0.058$ & $0.02 \pm 0.01$ & Cote d'Voire \\
\hline Cherie Claire & CC & $0.008 \pm 0.001$ & $0.01 \pm 0.00$ & Cote d'Voire \\
\hline Claire Plus & $C P$ & $0.145 \pm$ & ND & Cote d'Voire \\
\hline Clair-Liss Genial & CLG & $<0.001$ & $0.04 \pm 0.02$ & Cote d'Voire \\
\hline Cocoderm & $C D$ & $0.067 \pm 0.046$ & $0.83 \pm 0.51$ & Cote d'Voire \\
\hline Cocoon Cocoa Butter & $\mathrm{CCB}$ & $0.059 \pm 0.012$ & ND & Cote d'Voire \\
\hline Eclat $^{\circledR}$ Gel & EG & $0.327 \pm 0.062$ & ND & Cote d'Voire \\
\hline Extra Toning Cocoa Butter & ETCC & $0.096 \pm 0.029$ & $0.04 \pm 0.00$ & Cote d'Voire \\
\hline Fair and Light & $\mathrm{FL}$ & $<0.001$ & ND & Cote d'Voire \\
\hline$G \& G$ & GG & $<0.001$ & $0.01 \pm 0.00$ & Cote d'Voire \\
\hline Méticée & MT & $<0.001$ & $0.03 \pm 0.01$ & Cote d'Voire \\
\hline Miss Caroline & MC & $0.256 \pm 0.045$ & $0.02 \pm$ & Cote d'Voire \\
\hline Palmas Cocoa Butter & PCB & $0.001 \pm 0.000$ & ND & Cote d'Voire \\
\hline PỐlisse & $\mathrm{PL}$ & $<0.001$ & ND & Cote d'Voire \\
\hline Sivoclair & SC & $<0.001$ & ND & Cote d'Voire \\
\hline Sure White & SW & $0.140 \pm 0.045$ & $0.01 \pm 0.00$ & Cote d'Voire \\
\hline Victory white & VW & $0.003 \pm 0.001$ & ND & Cote d'Voire \\
\hline Clear N Smooth Cream & CNS & $<0.001$ & ND & Italy \\
\hline Esapharma MOVATE Cream & EMC & $0.166 \pm 0.123$ & ND & Italy \\
\hline Fashion Fair Cream & FFC & $0.001 \pm 0.000$ & ND & Italy \\
\hline L'abidjanaise $^{\circledR}$ Cream & LAC & $<0.001$ & ND & Italy \\
\hline Movate Cream & MTC & $0.026 \pm 0.003$ & $0.18 \pm 0.05$ & Italy \\
\hline Naturel Cream & NC & $0.008 \pm 0.005$ & ND & Italy \\
\hline Neo-vate White Cream Plus & NWCP & $<0.001$ & ND & Italy \\
\hline Neutrotone ${ }^{\circledR}$ Cream & NTC & $0.004 \pm 0.001$ & ND & Italy \\
\hline New Age Cream & NAC & $0.250 \pm 0.031$ & ND & Italy \\
\hline New Skin Light ${ }^{\circledR}$ Cream & NSLC & $0.002 \pm 0.001$ & ND & Italy \\
\hline Perfect Skin & PS & $0.122 \pm 0.057$ & ND & Italy \\
\hline Polux Gel & $P G$ & $0.001 \pm 0.000$ & ND & Italy \\
\hline Skin Maxitoner & SM & $0.015 \pm 0.004$ & ND & Italy \\
\hline Skin Solution Cream & SSC & $0.067 \pm 0.025$ & $0.51 \pm 0.18$ & Italy \\
\hline Skinicles Cream & $\mathrm{SCC}$ & $0.152 \pm 0.079$ & $0.19 \pm 0.04$ & Italy \\
\hline Swiss Formula Cream & SFC & $0.046 \pm 0.029$ & $0.02 \pm 0.01$ & Italy \\
\hline Crusader ${ }^{\circledR}$ Ultra Brand & CUB & $0.135 \pm 0.085$ & ND & UK \\
\hline Dermatological E45 Solution & DES & $0.192 \pm 0.097$ & ND & UK \\
\hline Zarina Cream & ZC & $0.070 \pm 0.031$ & $1.61 \pm 0.72$ & UK \\
\hline Sukisa Bango & SB & $0.228 \pm 0.023$ & ND & UK \\
\hline Amiderm Cream & $A C$ & $0.043 \pm 0.015$ & $0.20 \pm 0.11$ & India \\
\hline Betasol Cream & $B C$ & $0.081 \pm 0.031$ & $0.20 \pm 0.02$ & India \\
\hline Chocho Skin Toner & CST & $<0.001$ & ND & India \\
\hline Closol Cream & $\mathrm{CLC}$ & $0.060 \pm 0.039$ & $0.32 \pm 0.16$ & India \\
\hline Epiderm $^{\mathrm{TM}}$ Cream & EC & $<0.001$ & ND & India \\
\hline Funbact-A & FA & $0.081 \pm 0.048$ & ND & India \\
\hline Surfaz Cream & SFC & $0.182 \pm 0.057$ & $0.01 \pm 00$ & India \\
\hline Dawmy & DW & $<0.001$ & ND & USA \\
\hline Dr. Fred Summit Skin Whitener & DFSW & $0.106 \pm 0.028$ & ND & USA \\
\hline BioClaire & $\mathrm{BCL}$ & $<0.001$ & ND & Indonesia \\
\hline
\end{tabular}


Table 1 continued

\begin{tabular}{lllll}
\hline Product name & $\begin{array}{l}\text { Acronym } \\
\text { for product }\end{array}$ & Mercury $(\boldsymbol{\mu g} / \mathbf{g})$ & Hydroquinone (\%) & Country of origin \\
\hline Hyprogel & HG & $0.076 \pm 0.015$ & ND & Germany \\
So sexy & SS & $0.145 \pm 0.091$ & ND & Senegal \\
Mercy Ointment & MO & $<0.001$ & ND & Ghana \\
The Karibu D'or Sana & TKD & $0.166 \pm 0.026$ & ND & China \\
Dove Silk Cream & DSC & $0.015 \pm 0.002$ & $0.40 \pm 0.71$ & Nigeria \\
\hline
\end{tabular}

ND not detected

Table 2 Levels of mercury and hydroquinone concentrations in cosmetic soaps

\begin{tabular}{|c|c|c|c|c|}
\hline Product name & $\begin{array}{l}\text { Acronym } \\
\text { for product }\end{array}$ & Mercury ( $\mu \mathrm{g} / \mathrm{G})$ & Hydroquinone (\%) & Country of origin \\
\hline Carotone soap & CTS & $0.148 \pm 0.085$ & $0.02 \pm 0.01$ & Cote d'Voire \\
\hline Black Velvet soap & BVS & $0.003 \pm 0.000$ & ND & Italy \\
\hline Classic White soap & CWS & $0.204 \pm 0.065$ & $0.05 \pm 0.03$ & Indonesia \\
\hline Pharmapur (soap) & PPS & $0.027 \pm 0.015$ & ND & Turkey \\
\hline Be White Whiteniser soap & BWS & $0.214 \pm 0.059$ & ND & UK \\
\hline Crusader $^{\circledR}$ medicated soap & CMS & $0.337 \pm 0.073$ & ND & UK \\
\hline Skin success complexion toning soap & SCTS & $0.017 \pm 0.009$ & ND & UK \\
\hline Tura soap & TS & $0.272 \pm 0.089$ & ND & Nigeria \\
\hline
\end{tabular}

ND not detected

from Cote d'Voire ranged from $<0.001$ to $0.327 \pm 0.062$, $<0.001$ to $0.250 \pm 0.031$ in creams imported for Italy and $<0.001$ to $0.182 \pm 0.057$ in creams imported from India. About $28 \%$ of the creams recorded T-mercury concentration below detection $(<0.001 \mu \mathrm{g} / \mathrm{g})$. The highest concentration of T-mercury was recorded in EG which is imported from Cote d'Voire. T-mercury concentration in soaps ranged from $0.003 \pm 0.000$ to $0.337 \pm 0.073 \mu \mathrm{g} / \mathrm{g}$. All the skin-lightening creams and soaps analysed had T-mercury concentration below $1.0 \mu \mathrm{g} / \mathrm{g}$ maximum limit set by the United States Food and Drug Administration (USFDA) (USFDA 2009). Similar results were reported by Voegborlo et al. (2008). However, previous studies conducted by Al-Saleh and Al-Doush (1997) on mercury concentration in creams obtained from the Saudi Arabians market which originated from Asia and Middle East contained T-mercury concentration above the US FDA limit. Results of T-mercury determined in cosmetic products obtained on Dares Salaam market in Tanzania also showed very high concentration of mercury in some creams and soaps above the US FDA limit with T-mercury ranged from 0.11 to $8665 \mu \mathrm{g} / \mathrm{g}$ in cosmetic soaps and $0.16-25.30 \mu \mathrm{g} / \mathrm{g}$ in cosmetic creams (Kinabo 2003).

Hydroquinone levels in the skin-lightening products ranged from below detection to $0.83 \pm 0.51 \%$ in creams imported from Cote d'Voire, $0.02 \pm 0.01$ to $0.51 \pm 0.18 \%$ in creams imported from Italy, below detection to $0.32 \pm 0.16 \%$ in creams imported from India. Creams originating from USA, Indonesia, Germany, Senegal, Ghana and China recorded hydroquinone levels below the detection limit. The highest concentration of hydroquinone was recorded in $\mathrm{ZC}(1.61 \pm 0.72 \%)$ imported from UK followed by CD $(0.83 \pm 0.51 \%)$ imported from Cote d'Voire, Skin Solution Cream $(0.51 \pm 0.18 \%)$ imported from Italy, DSC $(0.40 \pm 0.71 \%)$ imported from Nigeria and CLC $(0.32 \pm 0.16 \%)$ imported from India. Hydroquinone levels in the skin-lightening soaps ranged from below detection to $0.05 \pm 0.03 \%$. Classic white soap and CTS recorded hydroquinone concentration of $0.05 \pm 0.03$ and $0.02 \pm 0.01 \%$, respectively. Overall, $64 \%$ of the creams and $75 \%$ of soaps analysed recorded hydroquinone concentrations below detection. All the skin-lightening creams and soaps analysed recorded hydroquinone concentration below the US FDA threshold limit of $2 \%$ (USFDA 2009). Doreen (2010) recorded levels of hydroquinone (0.001-3.45 \%) in some skin lighteners in Ghana, which was higher than the present study. However, levels of hydroquinone $(0.0002-0.0350 \%)$ in body creams and lotions by Terer et al. (2013), Kenya are comparable with the present study. 


\section{Conclusion}

The results for total mercury and hydroquinone levels in skin lightening creams and soaps obtained in this study are below the limits set by United States Food and Drug Administration (USFDA). The use of these creams and soaps do not pose any health risk to Ghanaian women so far as mercury and hydroquinone levels are concern. Though the samples analysed in this study do not contain high levels of total mercury and hydroquinone, their continuous use may pose health threat since hydroquinone and mercury can accumulate in the liver and kidneys which can cause damage to these organs.

\section{Authors' contributions}

All the authors contributed equally to the preparation of this manuscript. All authors read and approved the final manuscript.

\section{Acknowledgements}

The authors are very grateful to the National Council for tertiary Education (NTCE), Ghana for a research grant under the Teaching and Learning Innovation Fund (TALIF-KNUSTR/3/005/2005).

\section{Competing interests}

The authors declare that they have no competing interests.

Received: 21 June 2015 Accepted: 3 March 2016

Published online: 11 March 2016

\section{References}

Adebajo S (2002) An epidemiological survey of the use of cosmetic skin lightening cosmetics among traders in Lagos, Nigeria. West Afr J Med 21(1):51-55

Akagi H, Nishimura H (1991) Speciation of mercury in the environment. In: Suzuki T, Imura N, Clarkson TW (eds) Advances in mercury toxicology. Plenum Press, New York, pp 53-76

Aldrich (1990) Catalog/Handbook of fine chemicals. Aldrich Chemical Company, Milwaukee, WI, p 235

Al-Saleh I, Al-Doush I (1997) Mercury content in skin lightening creams and potential hazards to the health of Saudi women. J Toxicol Environ Health 51:123-130

Amponsah D, Sebiawu GE, Voegborlo R (2014) Determination of amount of mercury in some selected skin-lightening creams sold in the Ghanaian market. Int J Eng Res Technol 3(6):344-350
Barr RD, Woodger BM, Rees PH (1973) Levels of mercury in urine correlated with the use of skin lightening creams. Am J Clin Pathol 59:36-40

Bourgeosis M, Dooms-Goossens A, Knockaert D, Sprenger D, Vsan Boven M, Van tittelboom T (1986) Mercury intoxication after topical application of a metallic mercury ointment. Dermatologica 172:48-51

Doreen A (2010) Levels of hydroquinone and mercury in skin lightening creams and their potential risk to the health of consumers in Ghana. Unpublished Master's dissertation, Kwame Nkrumah University of Science and Technology, Kumasi, Ghana

Glahder CM, Appell PWU (1999) Mercury in soap in Tanzania. NERI Technical Report No. 306. Department of Arctic Environment Geological Survey of Denmark and Greenland, p 19

Harada M, Nakachi S, Tasaka K, Sakashita S, Muta K, Yanagida K, Ohno H (2001) Wide use of skin-lightening soap may cause mercury poisoning in Kenya. Sci Total Environ 269(1-3):183-187

Hutson DH, Dean BJ, Brooks TM, Hudson-Walker G (1999) Genetic toxicology testing of 41 industrial chemicals. Research 153:57-77

Joseph P, Klein-Szanto AJP, Jaiswal AK (1998) Hydroquinones cause specific mutations and lead to cellular transformator and in vivo tumorgenesis. $\mathrm{Br}$ J Cancer 78(3):312-320

Kahatano JMJ, Mnali SR, Akagi H (1998) A study of mercury levels in fish and humans in Mwakkitolyo mine and Mwanza town in the Lake Victoria gold-fields, Tanzania. Br Med J 2:543-545

Kinabo CP (2003) Comparative analysis of mercury content in human hair and cosmetics products used in Dar es salaam, Tanzania. J Pharm Pharmacol 2:23-45

Lewis K, Robkin N, Gaska K, Njoki LC, Andrews E, Jetha K (2009) The Tanzanian response to dangerous skin bleaching products and practices and the gendered politics of it all: a critical analysis. J Cult Afr Women Stud 10:18-35

Mahe A, Ly F, Gounongbe A (2004) The cosmetic use of bleaching products in Dakar, Senegal: socio-economic factors and claimed motivations. Sciences Sociales Et Sante 22(2):5-33

Miller JC, Miller JN (1988) Statistics for analytical chemistry, 2nd edn. Ellis Horwood Limited Publishers, Chichester, pp 101-117

Perry I (2006) Buying white beauty. Cardozo J Law Gend 12:579-607

Sah RC (2012) Poisonous cosmetics, the problem of mercury in skin whitening creams in Nepal, vi+10. CEPHED, Kathmandu

Terer EK, Magut H, Mule S (2013) UV-Vis analysis and determination of hydroquinone in body lotions and creams sold in retail outlets in Baraton, Kenya. Baraton Interdispl Res J 3(1):23-28

USFDA (2009) United State Food and Drug Administration supporting information for toxicological evaluation by the National toxicology program 21 May 2009

Voegborlo RB, Agorku ES, Buabeng-Acheampong B, Zogli E (2008) Total mercury content of skin toning creams and the potential risk to the health of women in Ghana. J Sci Technol 28(1):88-94

Yoshimura K, Tsukamoto K, Okazaki M, Virador VM, Lei T-C, Suzuki Y, Uchida G, Kitano Y, Harii K (2001) Effects of all-trans retinoic acid on melanogenesis in pigmented skin equivalents and monolayer culture of melanocytes. J Dermatol Sci 27:68-75

\section{Submit your manuscript to a SpringerOpen ${ }^{\circ}$ journal and benefit from:}

- Convenient online submission

- Rigorous peer review

- Immediate publication on acceptance

- Open access: articles freely available online

- High visibility within the field

- Retaining the copyright to your article

Submit your next manuscript at $>$ springeropen.com 